\title{
A CENOGRAFIA PARA A COMEMORAÇÃO DO CASAMENTO DE DOM JOÃO VI E DONA CAR- LOTA JOAQUINA EM 1786 NO RIO DE JANEIRO
}

Resumo

$>$

Este artigo apresenta a cenografia empregada na festa de celebração do casamento de D. João VI e Da. Carlota Joaquina, em 1786, no Rio de Janeiro. A celebração, descrita no livreto Relação dos Magníficos carros, que se fizeram de arquitetura, perspectiva e fogos, tem destacada importância, por ser um dos mais importantes, e talvez o mais antigo, conjunto de desenhos produzidos no Brasil até 1786, como documento de festa popular, repleta de teatralidade.

Palavras-chave:

Cenografia. Traje de cena. Brasil colonial. 


\title{
A CENOGRAFIA PARA A COMEMORAÇÃO DO CASAMENTO DE DOM JOÃO VI E DONA CARLOTA JOAQUINA EM 1786 NO RIO DE JANEIRO
}

\author{
Fausto Viana (USP)' \\ Isabel Cristina Italiano (USP)²
}

\footnotetext{
Professor livre docente de cenografia e indumentária do Departamento de Artes Cênicas da Universidade de São Paulo. E-mail:

faustoviana@uol.com.br.

${ }^{2}$ Professora livre docente de têxtil e moda na Escola de Artes, Ciências e Humanidades da Universidade de São Paulo. E-mail:

isabel.italiano@usp.br.
}

Este artigo apresenta um estudo sobre a cenografia - e por cenografia entende-se aqui literalmente a grafia da cena e tudo que nela interfere, quais sejam: cenários, figurinos, iluminação e até mesmo sons e outros elementos - empregada na celebração do casamento de Dom João VI e Dona Carlota Joaquina em 1786. A leitura deste artigo se complementa com a consulta ao artigo de Fausto Viana, The Clothes Worn in 1785 for the Betrothal and Wedding of Carlota Joaquina of Spain and Dom João of Portugal, publicado no The Journal of Dress History, Volume 1, Issue 2, Autumn 2017, da The Association of Dress Historians, London, England, p 84-993. Naquele artigo, apresentam-se os dados biográficos dos envolvidos e os trajes usados na festa de casamento em Lisboa e em Madri. As celebrações de casamento da realeza podiam acontecer em diversas cidades, e as festas nas colônias de países como Portugal eram uma constante nos séculos em que esta dominação aconteceu.

No Rio de Janeiro houve uma grande celebração do ca-

3 Disponível em <https://docs.wixstatic.com/ugd/ebc4ea_f3419f56a12c43f2a6f4fc624fb35e73.pdf $>$. Acesso em 8 jan. 2019. 
samento, promovida pelo Vice-Rei Luís de Vasconcelos (1742-1809) em 1786, ou seja, um ano depois do casamento que aconteceu em 1785! 230 anos depois, fica o questionamento sobre o que foi construído de cenografia e figurinos para esta festa alegórica. Indaga-se como foi possível executar os seis carros alegóricos que, como será visto, foram construídos. Investiga-se quais eram as prováveis formas de confecção dos trajes empregados. É nessa perspectiva que este artigo se desenrola: encontrando as formas de produção teatral no século XVIII, no Brasil dominado pelos portugueses, e mostrando que a criação cenográfica no evento foi uma das maiores produções feitas no país, no século XVIII.

A principal fonte documental empregada é justamente um conjunto de desenhos feito pelo idealizador e executor dos carros, Antônio Francisco Soares, que encadernou os desenhos em um livreto que tem o extenso nome: Relação dos Magníficos carros, que se fizerão de arquitetura, perspectiva e fogos. Os quais, se executaram Por Ordem do Illust.mo e Excel.mo Senhor Luis de Vasconcelos, Capitão General de Mar e Terra, e Vice Rei dos Estados do Brazil, nas Festividades dos Despozorios Dos Serenissimos Senhores Infantes de Portugal - Nesta Cidade Capital do Rio de Janeiro. Em 2 de Fevereiro de 1786. Feita na Praça mais Lustroza, e publica do passeio desta cidade. Executados, e ideados, pelo O mínimo subdito Antônio Fran.co Soares Ajudante agregado.

O livreto, deste momento em diante chamado apenas de Relação dos Magníficos Carros, foi doado ao Instituto Histórico e Geográfico do Rio de Janeiro no século XX pelo pintor e professor Manuel de Araújo Porto-Alegre (1806-1879). Tem 30 páginas de texto e mais 8 de ilustrações. As figuras verticais têm $21 \times 17 \mathrm{~cm}$ e as horizontais, $31 \times 19 \mathrm{~cm}$. A edição é toda manuscrita e as figuras e o texto foram feitos com tinta preta (nanquim?) sobre papel. Não há nenhuma figura ou texto colorido.

A equipe do Núcleo de traje de cena, indumentária e tecnologia da Universidade de São Paulo está preparando uma edição com revisão crítica do trabalho elaborado em 1786 por Antônio Francisco Soares, com lançamento previsto para finais de 2019.

\section{O processo do casamento}

Todo o procedimento descrito a seguir precisa ser entendido no contexto sócio-político-econômico do século XVIII, e não sob a óptica da contemporaneidade. As relações maritais, principalmente as da nobreza, não eram baseadas em amor ou atração pessoal entre casais, como se poderia esperar entre os casamentos modernos. A festa de casamento que se vai analisar era entre duas casas imperiais europeias significativas em termos políticos e financeiros: os Bourbon e os Bragança, que tinham histórias que datavam dos séculos XIII e XVII, respectivamente.

Carlota Joaquina (1775-1830) era filha de Carlos IV da Espanha e descendente do Rei Luís XIV da França. Dom João (1767-1826), que viria a ser Dom João VI, Rei de Portugal, Brasil e Algarves era filho de Pedro III e da Rainha Dona Maria I, ambos de Portugal.

A intenção de casamento entre os dois membros das casas imperiais de Portugal e Espanha tinha sido discutida já no final da década de 1770. Como Rui Ramos afirma em seu livro História de Portugal:

Os primeiros anos do reinado de D. Maria I ficaram também assinalados por uma política de aproximação a Espanha, patrocinada ainda pelo rei Carlos III. Foi nesse contexto que se celebraram, em 1785, os casamentos cruzados do infante D. João e da infanta D. Mariana Vitória com os infantes de Espanha, respectivamente, D. Carlota Joaquina e D. Gabriel Antônio (RAMOS, 2012, p. 427).

O primeiro contrato de casamento entre os dois infantes foi assinado no dia 2 de maio de 1784, em Aranjuez, na Espanha. Eram na verdade os "artigos preliminares para o tratado matrimonial", e foram assinados pelos enviados das duas coroas: por parte da rainha Fidelíssima D Maria I, Dom Henrique de Menezes, o Ter- 
ceiro Marquês de Louriçal e por parte de El-Rei Católico Carlos III, Dom José Moñino y Redondo, o Conde de Floridablanca.

Ainda em 1784, e, portanto, um ano antes do casamento em si, no Palácio Ducal de Vila Viçosa, uma das moradias da Casa dos Bragança, distante 187 quilômetros de Lisboa, a criadagem já começava a preparar a comemoração. No dia 10 de março de 1785 , um novo tratado de casamento foi assinado. No dia 27 de março de 1785 , uma escritura e um contrato matrimonial foram assinados em Madri, na presença do Conde de Florida Blanca e do Marquês de Louriçal. Na ocasião, Dom Henrique de Meneses ergueu um pavilhão efêmero para as festividades e recebeu 2.000 convidados entre 27 e 29 de março. Os noivos não estavam presentes.

Dona Carlota Joaquina de Bourbon surpreendeu Dom João e seus pais quando chegou ao Palácio Ducal de Vila Viçoza, em 8 de maio de 1785: "Ela não era apenas uma criança, era extremamente pequena e de aparência pouco atrativa, com cabelo encaracolado e um ar deselegante" (ROBERTS, 2009, p.116). Carlota Joaquina tinha então 10 anos de idade, muito mais jovem do que sua sogra, Dona Maria I, que tinha 25 anos na ocasião de seu casamento com D. Pedro III, que era seu tio biológico. Era a mesma idade, no entanto, com que havia se casado Dona Mariana Vitória de Áustria, a mãe de Dona Maria I.

Mariano Salvador Maella pintou o retrato de Dona Carlota Joaquina (Figura 1) em 1785, ano em que ela se casou com o infante Dom João (Figura 2). Esta intensa rede de casamentos reais, muitas vezes envolvendo pessoas ainda mais jovens, era uma forma de garantir poder político, unir fortunas e assegurar propriedades.

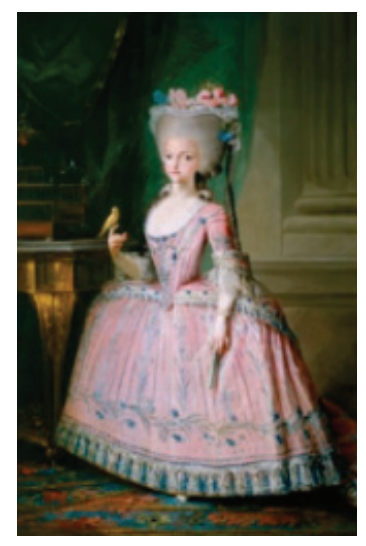

Figura 1 - Carlota Joaquina de Espanha. Mariano Salvador Maella, 1785, óleo sobre tela, 177 cm x 116 cm, Museu do Prado, Madri, Espanha, P02440.

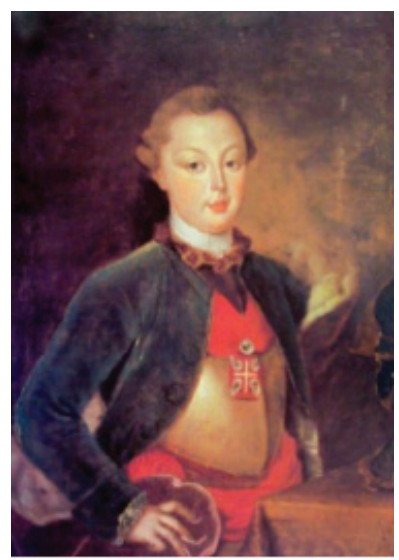

Figura 2 - Dom João enquanto criança, artista desconhecido, final do século XVIII, Museu da Inconfidência, Ouro Preto, Brasil.

Naquele 8 de maio de 1785 houve uma cerimônia religiosa e uma grande festa celebrando o evento, que assim foi noticiada pela Gazeta de Lisboa:

Toda a Família Real jantou em público: cerimônia que se não havia praticado desde os Reais Desponsórios do ano 1729. A família e comitiva espanhola jantou em várias mesas de Estado, servidas com magnificência, profusão e delicadeza (JARDIM, 2012, p. 25).

Era de se esperar que o evento todo assim se desenvolvesse, dada a nobreza e tradição das duas famílias envolvidas:

A família Real dos Bragança data dos anos de 1640 (tendo ramificações, através da Casa de Borgonha, que chegam a 1442) e a Casa Real dos Bourbon começou a reinar na Espanha 
em 1700, com Filipe V, neto do Rei da França Louis XVI. A família Real dos Bourbon na França já reinava desde 1268 (VIANA, 2017, p.87).

Em 9 de junho de 1785, houve uma cerimônia religiosa na Capela da Real Barraca, em Lisboa. Depois da cerimônia, ocorreram três dias de festividades, com uma grande queima de fogos na Praça do Comércio.

\section{A celebração do casamento no Brasil}

Luís de Vasconcelos e Souza (17421809) (Figura 3 ) era o $4^{\circ}$ Conde de Figueiró e foi vice-rei do Brasil entre 1778 e 1790. Fez importantes obras no Rio de Janeiro, entre elas a do Passeio Público. Sonia Gomes Pereira, professora de história da arte na Escola de Bela Artes da Universidade Federal do Rio de Janeiro, é taxativa ao afirmar que o casamento dos dois infantes era uma oportunidade única, e as festas foram feitas

com a explícita intenção de exceder a tudo que tinha sido feito até então no Rio de Janeiro. Tanto a imponência como a duração dos festejos marcaram época na cidade. (...) Esta comemoração durou três dias, de 2 a 4 de fevereiro de 1786, mas estendeu-se de forma mais esparsa até 28 de maio. Constou pelo menos de touradas e cavalhadas, além do desfile de carros. Para servir de arena às cavalhadas, foi construído um anfiteatro no Campo da Lapa do Desterro. O Passeio Público foi todo iluminado e ornamentado, e recebeu uma arquibancada com camarotes ${ }^{4}$.

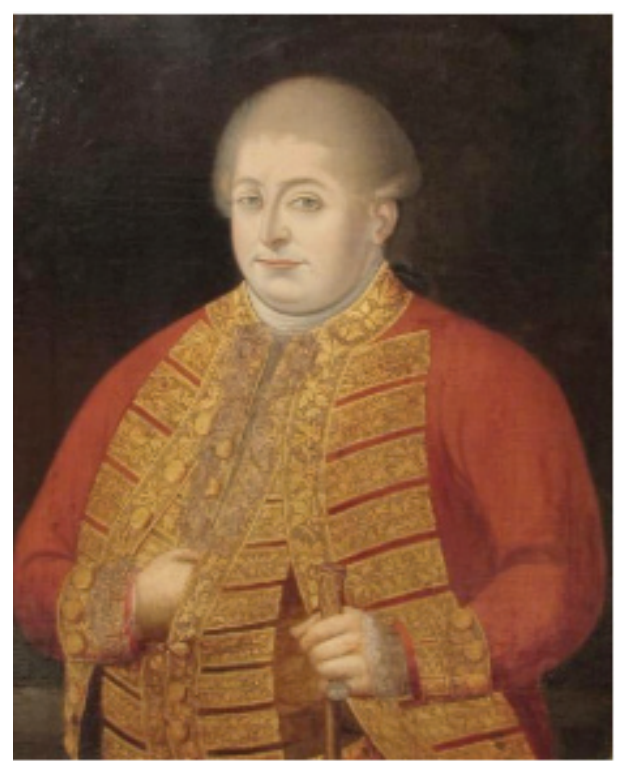

Figura 3 - Luís de Vasconcelos e

Souza. Leandro Joaquim, c. 1790.

Museu Histórico Nacional, Rio de Janeiro, Brasil.

Nireu Cavalcanti complementou que a programação contou ainda, nos meses de janeiro e fevereiro de 1786, com eventos "tradicionais, como o tríduo de missas na Igreja de São Bento, as óperas, os saraus musicais e outros 'festejos em obséquio dos felizes desponsórios dos Sereníssimos Infantes"' (CAVALCANTI, 2004, p. 330).

Neste artigo, o foco se restringirá aos trabalhos apresentados no livreto Relação dos magnânimos carros. Nele, o autor Antônio Francisco Soares descreve seis carros alegóricos que apresentavam uma cena independente em cada carro, tanto que não desfilaram juntos. Os carros, como será visto, tinham um tema (ligado à mitologia greco-romana), atores sobre ele e alguns ao seu redor ou conduzindo-o, música e iluminação próprias, quer fossem lamparinas, quer fossem fogos de artifício.

A Relação dos magníficos carros não é uma coletânea de desenhos e textos feitos previamente, antes de algum evento. Ao contrário, a Relação é uma descrição pós-evento, em que o autor narra o que já aconteceu. Essa coletânea é um dos mais importantes conjuntos de dese-

\footnotetext{
${ }^{4}$ Ver PEREIRA, Sonia Gomes. Festas públicas e desenvolvimento urbano no Rio de Janeiro do século XVIII. Disponível em <https://www.upo.es/depa/webdhuma/areas/arte/3cb/documentos/101f.pdf.>. Acesso em 14 jan. 2019.
} 
nhos que foram produzidos no Brasil até 1786, e não se conhece, por enquanto, um documento mais antigo com este cunho de festa popular e repleta de teatralidade.

\section{Os carros alegóricos}

Apesar de vários artigos direcionarem o trabalho com estes carros alegóricos ao carnaval carioca, os carros foram feitos, de fato, com o objetivo principal de comemorar o casamento dos dois infantes, D. Carlota Joaquina e D. João, que não estiveram no Rio de Janeiro e nem no Brasil no ano de 1785 - só viriam a fazê-lo em 1808, quando saíram da sede administrativa do Império Português - Portugal - para o Brasil. Aproveitando o ensejo, fizeram uma bela homenagem, algo bajulativo, ao vice-rei Dom Luís de Vasconcelos, que clamava ter feito trabalhos importantes para a cidade e merecia que seus méritos fossem louvados - ainda que no meio das festas comemorativas do enlace de dois soberanos.

Antes de descrever os carros, finalidade maior do trabalho a que se propunha, o autor dedica ao vice-rei alguns versos - o que não era incomum no período, até mesmo em livros de caráter científico. Agradecia-se a alguma autoridade ou governador, mas eis que Soares redige o seguinte poema em dez versos, uma décima, para o senhor vice-rei:

\author{
O vosso nome Luiz, \\ Um claro enigma produz, \\ Pois tirando o I, sois Luz, \\ E tirando o U, sois Liz (nota: da flor de lis) \\ Estes dois caracteres quis \\ Que para os vossos louvores \\ Fossem fiéis mostradores \\ De que sois com energia \\ Flor de lis, na bizarria,
}

Luz do Sol, nos resplendores ${ }^{5}$.

Há também um soneto, algo excessivo no que tange aos elogios ao senhor vice-rei:

Magnânimo Luiz, Vice Rei puro Sem nota no estado da equidade Vassalo o mais leal à majestade

Da ciência e valor monte seguro.

Da grandeza, que vejo conjecturo Que as vossas obras têm tal raridade, Que se viu na Real Festividade

Dares normas aos mais para o futuro.

Na portentosa ideia, que escolhestes Com bem cara evidência viu-se o quanto Aos mais festejos todos excedestes;

Porque a pompa subiu de ponto tanto No aplauso, em que Sábio floresceste, Que de admiração passou a espanto ${ }^{6}$.

Esperava-se que os carros alegóricos fossem trabalhados para a maior glória dos infantes, o que aconteceu apenas em alguns momentos e, notadamente, no Quarto Carro, o dos Mouros, como será visto. Mas a presença da homenagem ao vice-rei esteve presente o tempo todo.

O uso de carros alegóricos, ou festivos, não era uma novidade no teatro ocidental. Margot Berthold destaca alguns momentos em que eles foram utilizados, como no teatro grego, cerca de 500 antes de Cristo, quando o clímax de uma procissão

era o carro festivo do deus (Dioniso) puxado por dois sátiros, uma espécie de barca sobre rodas (carrus navalis ${ }^{7}$ ), que carregava a imagem do deus ou, em seu lugar, um ator coroado de folhas de videira. O carro-barca recorda as aventuras marítimas do deus, pois, de acor-

\footnotetext{
${ }^{5}$ Relação dos magníficos carros, p. 4. A questão da grafia é apenas um detalhe para o entendimento e "apreciação" dos versos, já que a grafia de lis, da flor de lis, é atualmente feita com s. Bizarria também tinha outro significado aqui, conforme consultou-se no dicionário do padre Bluteau, na p. 130: Bizarria significa graça, garbo, gala.

${ }^{6}$ Idem, p. 5.

${ }^{7}$ Felipe Ferreira, em O Marquês e o jegue: estudo da fantasia para escolas de samba, estabelece que o nome carrus navalis, ligado ao barco processional (ainda que ele se refira ao culto à deusa Ísis) é aceito por aqueles que entendem o carnaval como uma festa de origem pagã. Para aqueles que entendem que o carnaval seja uma festa de proveniência cristã, ele diz que a palavra carnaval "seria derivada então de carne vale, ou carnis levamem" (FERREIRA,1999, p. 37) ou seja, "adeus à carne", já que começaria o período da quaresma.
} 
do com o mito, Dioniso, quando criança, fora depositado na praia pelas ondas do mar, dentro de uma arca (BERTHOLD, 2010, p.105).

Já com a conotação de carro-palco, ou seja, muito próximo ao que será visto nos carros alegóricos do Rio de Janeiro em 1785, Berthold descreve que "as origens do carro-palco remontam a 1264, quando o Papa Urbano IV instituiu a festa de Corpus Christi, que foi depois celebrada com procissões solenes por toda a Europa ocidental", para complementar, em sequência, que

A peça frequentemente derivava da procissão teatralmente plasmada. Além da sua origem no ensejo religioso cerimonial, a peça de teatro possui também raízes seculares nos torneios e nos cortejos de rua, que se organizavam em homenagem aos soberanos e que foram os precursores dos grandes trionfi alegóricos da Renascença (Idem, p.208).

As alegorias - e a palavra vem do grego, e quer dizer "falar de maneira a dizer outra coisa"8 - são representações em que personagens, imagens e eventos agem como símbolos. A alegoria é uma metáfora estendida, que vai além da comparação - sempre há algo sob a superfície do que se está vendo. Na renascença, como cita Bryan Holme, um artista ou era apoiado pela igreja ou algum

nobre, mercado bem-sucedido ou, se desse a sorte de ser florentino, um dos banqueiros Medici. Ele poderia então trabalhar em uma Procissão de magos, para uma capela privativa [...]., pintar um retrato de família ou elaborar alegorias como a Paz, Amizade ou talvez O triunfo da virtude sobre o vício. As alegorias também se tornaram temas para as mascaradas, ou pageant plays que eram realizadas na Itália e depois, com mais frequência, na Inglaterra (HOLME, 1988, p. 6).

No Brasil, Paulo Romualdo Hernandes destaca um evento ocorrido em 1584: uma representação feita por estudantes do Colégio de Jesus. Assim ele a descreve:

Cardim faz uma descrição de uma representação feita pelos estudantes em Salvador, (...) em 1584, tempo (aproximado) e lugar em que se supõe tenha sido realizada a peça "Diálogo de Pero Dias": Ao dia seguinte, por ser dia das Onze Mil Virgens, houve no colégio grande festa da confraria das Onze Mil Virgens, que os estudantes têm a seu cargo, disse missa cantada um padre diácono e subdiácono. Os padrinhos foram o padre Luís da Fonseca, reitor, e eu com nossas capas de asperges. A missa foi oficiada com boa capela dos Îndios, com flautas e de alguns cantores da Sé, com órgãos, cravos e descantes. E, ela acabada, se ordenou a procissão dos estudantes, aonde levamos debaixo do pálio três cabeças das Onze Mil Virgens, e as varas levaram os vereadores da cidade, e os sobrinhos do Sr. governador. Saiu na procissão uma nau à vela por terra, mui formosa, toda embandeirada, cheia de estudantes, e dentro nela iam as Onze Mil Virgens ricamente vestidas, celebrando seu triunfo (grifo nosso) ${ }^{9}$.

Hernandes, ainda reportando o que o padre Cardim disse, diz que:

De algumas janelas falaram à cidade, colégio, uns anjos todos mui ricamente vestidos. Da nau se dispararam alguns tiros de arcabuzes, e o dia de antes houve muitas invenções de fogo, na procissão houve danças, e outras invenções devotas e curiosas. Â tarde se celebrou o martírio dentro na mesma nau, desceu uma nuvem dos Céus, e os mesmos anjos lhe fizeram um devoto enterramento; obra foi devota e alegre, concorreu toda a cidade por haver jubileu e pregação ${ }^{10}$.

É possível perceber que houve intenso contato físico com o público, através dos índios tocando flauta,

danças de estudantes, de meninos índios e outras invenções curiosas, bem como adere-

\footnotetext{
${ }^{8}$ Ver <http://www.literarydevices.com/allegory/>. Acesso em 14 jan. 2019.

${ }^{9}$ Ver HERNANDES, Paulo Romualdo. José de Anchieta, o teatro e a educação dos moços do Colégio de Jesus na Bahia do século XVIII. Disponível em:

<https://periodicos.sbu.unicamp.br/ojs/index.php/histedbr/article/download/8640037/7596>. Acesso em 14 jan. 2019.

${ }^{10}$ Idem.
} 
ços cênicos. (Era uma obra) de teatro que teria forte influência [...] de modelos do teatro medieval; as alegorias, "cidade" e "colégio", a quem os anjos falaram das janelas das casas; a celebração do martírio dentro mesmo da Nau, que, segundo Leite, tinha "oito rodas de madeira escondidas". Tem também algo do maravilhoso teatro jesuítico, tal qual o da Baviera, nessa descrição: a celebração do martírio dentro da nau, em que desceu uma nuvem dos Céus, e os anjos fazendo um devoto enterramento ${ }^{11}$.

Em 1762, no mesmo Rio de Janeiro, também grandes festividades aconteceram pelo nascimento do primeiro filho de D. Maria I. Na ocasião, vários itens de arquitetura efêmera cenografia - foram construídos e espalhados pelas ruas do Rio.

Assim, em 1786, quando se decidiu construir carros alegóricos de madeira, isso já não era uma novidade, mas o requinte técnico com que foram construídos é que surpreende. Os carros foram confeccionados na Casa do Trem, que tinha sido aberta em 1762. Assim o Arsenal de Guerra do Rio explica quais eram as funções da casa do Trem:

Ao assumir o governo da Capitania do Rio de Janeiro, em 1733, Gomes Freire de Andrade - Conde de Bobadela - deparou-se com os crescentes avanços da tecnologia militar do século XVIII, percebendo a urgente necessidade de um depósito para a preservação dos materiais de guerra, sobretudo os de artilharia. Vislumbrava-se que nesse local, além de proteção contra o tempo, furtos, estragos e corrosões, os artefatos pudessem ser, também, reparados e até, quem sabe, fabricados. Nesse contexto, foi criada, em 1762, a "Casa do Trem", destinada a armazenar armamentos e munições e neles realizar pequenos reparos. O nome "trem" significava o conjunto de petrechos necessários à atividade bélica, também chamados de "Trem de Guerra". Assim, Gomes Freire de Andrade construiu a Casa do Trem, junto ao Forte de Santiago, na região que ficou conhecida, mais tarde, como Ponta do Calabouço. Nos dias atuais, a Casa do Trem insere-se no conjunto de edificações

\section{do Museu Histórico Nacional ${ }^{12}$.}

"O vice-rei contava não apenas com experiência anterior, mas poderia dispor agora dos recursos técnicos dos artesãos da Casa do Trem”, afirmou José Ramos Tinhorão, complementando que:

O desfile, que cumpriu longo trajeto para a época - rua da Misericórdia (ao pé do Morro do castelo, onde ainda funciona a Santa Casa carioca), da cadeia (atual Assembleia), Ourives (atual Rodrigo Silva), dos Barbonos (atual Evaristo da Veiga) e das Bela Noites (atual das Marrecas), fronteira ao portão do passeio Público - fazia esquecer, com a imponência de sua "arquitetura e fogos", a antiga "embarcação fingida" que entusiasmara os cariocas trinta anos antes, nas festas pelo nascimento do Príncipe da Beira (TINHORÃO, 2000, p. 113 e 114).

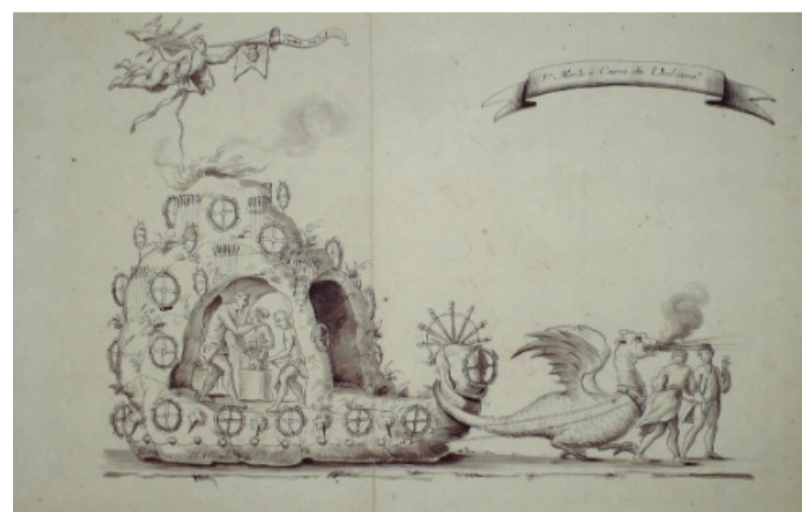

Figura 4 - O primeiro Carro e Monte de Vulcano. Acervo: IHGB.

O carro "Monte de Vulcano" tinha 5 metros de comprimento, 2,76 metros de largura e 4,60 metros de altura e foi feito para o primeiro dia das comemorações. Representava o Deus romano do fogo, Vulcano, que trabalhava dentro do carro batendo sua forja com seus oficiais - os ciclopes. Em cima do carro, como se estivesse voando, ia a figura da Fama, que levava uma corneta com as Armas Reais (na boca da corneta, a expressão fama volat ${ }^{13}$ e raios. Dois montanheses conduzem a serpente - que se

\footnotetext{
${ }^{11}$ Idem.

${ }^{12}$ Disponível em <http://www.agr.eb.mil.br/index.php/historico>. Acesso em 14 jan. 2019.

${ }^{13} \mathrm{~A}$ fama voa; a notícia se espalha rapidamente. O trecho está na Eneida, de Virgílio, Livro III, verso 121.
} 
assemelha muito a um dragão, mas tem uma cauda gigante que abraça o carro. De dentro do carro saíram $16^{14}$ bacantes, que dançaram para o público. Saíram ainda 12 montanheses com espadas e rodelas de fogo e travaram uma batalha. $\mathrm{O}$ carro era efeito de madeira, a pintura artística foi feita na Casa do Trem, e era bem realista, como descreve Soares no Magníficos carros: "era formado por um monte pintado com propriedade e com plantação de musgos, gravatás e árvore pequenas que tudo parecia criado pela natureza" (SOARES, 1786, p. 12). O carro era todo coberto por fogos de artifício, que terminadas as apresentações, foram queimados.

O carro também trazia músicos que tocavam dentro dele. $\mathrm{O}$ ator que fazia Vulcano declamou o seguinte texto:

Cesse o duro trabalho,

Ó, Estéropes e Brontes,

Cesse a bigorna de abalar os montes,

Nem sempre afoguçados

Os membrudos Ciclopes amarelos (?)

Farão soar os rígidos martelos.

Neste dia Himeneu, que venturoso

Da Ibéria, e Lusitânia a glória encerra,

Inunda de prazer o Céu e a terra

Dríadas e napeias

Em vistosas coreias

Unem os suavíssimos acentos

Ao grato som de acordes instrumentos:

O mesmo Apolo e as Musas se levantam,

E do Tejo feliz a glória cantam,

Do Tejo que entre paz, entre esperança

Se une ao Ebro em firmíssima aliança.

E enquanto eleva Jove ${ }^{15}$ Soberano

Ao claro Céu o nome Lusitano,

Povoem sem ruína

Raios de Luz a esfera cristalina

E voz também, deixando a forja dura,

Alegres respirai; e neste dia

Tudo seja prazer, tudo alegria. (Idem, p.16)

Em breve resumo, o que se deseja é que neste dia, os trabalhos duros sejam interrompidos para que se comemore o casamento dos infantes. É Himeneu, o deus grego do casamento, quem inunda de prazer o céu e a terra. Ninfas cantam em coro, com instrumentos acompanhando. Apolo (que é pai de Himeneu) canta com as musas, a união dos infantes - e por isso a menção ao Rio Tejo, de Portugal e ao Rio Ebro, da Espanha.

Cada carro tinha um apelo. O segundo carro era o de Júpiter, que era conduzido por uma águia, com as Armas Reais. Oito gigantes cercavam o carro de 3,5 metros de altura e eram derrotados por Júpiter, que estava em cima do carro e que tinha, também, um texto em que criticava os gigantes por tentarem perturbar a ordem, justamente quando os infantes celebravam a glória da sua união. Fazia também uma homenagem ao vice-rei com letras em fogo, onde se lia: "A Luiz se deve tudo". O terceiro carro era o de Baco, o deus do vinho que vinha louvar o casamento, mas também os bons vinhos portugueses do Alto Douro. Carregava sobre ele nove sátiros e um monte, sobre o qual estava instalado um nicho ricamente decorado com pinturas e elementos realistas. Este carro derramava vinho nas ruas. Não há nenhuma indicação, mas como o carro jorrava vinho por três bicas, era de se esperar que o público tomasse o vinho. $\mathrm{O}$ texto de Baco celebrava a vida e os bons vinhos. Havia música ao vivo no carro e os sátiros finalizavam a noite com uma dança.

$\mathrm{O}$ quarto carro era o do Imperador e Imperatriz (Figura 5), puxado por quatro cavalos que eram de uso do vice-rei. Era todo feito de madeira trabalhada e coberto de sedas "as mais primorosas de diversas cores, guarnecido com galões de ouro e prata com seus apanhados de velio(sic) ${ }^{16}$ de ouro e prata" (SOARES, 1786, p.18). Eram cerca de dez mouros e dois comparsas, além dos dois atores que faziam o (futuro) Imperador e a (futura) Imperatriz.

\footnotetext{
${ }^{14}$ Bacantes são sacerdotisas de Baco, mulheres consagradas aos mistérios desse deus mitológico.

${ }^{15}$ Júpiter.

16 Véu.
} 


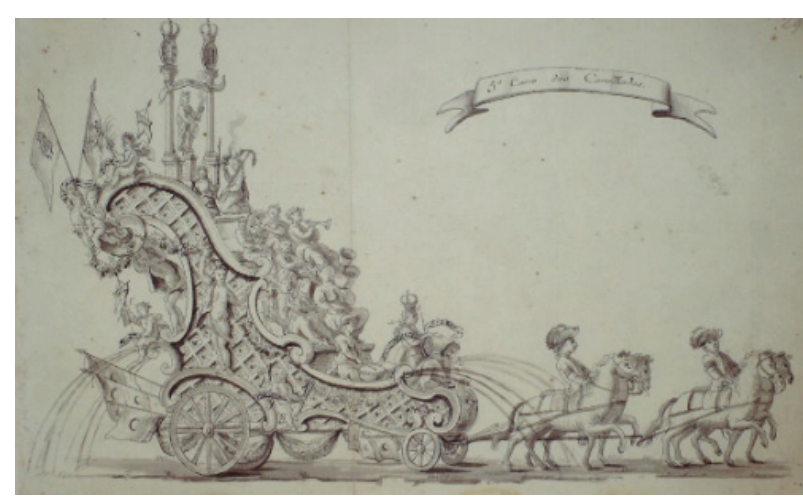

Figura 5 - O carro das cavalhadas. Acervo: IHGB.

O quinto carro (Figura 5) talvez seja o mais interessante sob vários aspectos. Foi o último a desfilar juntamente com o sexto carro, mas era uma composição longa. Tinha 4,60 metros de comprimento, 1,38 metros de largura na frente que abria para uma largura na parte detrás de 3,45 metros. A altura atingia quase 3 metros, fora o nicho onde ia o deus Himeneu. Era feito em madeira, com ornatos recortados no mesmo material, e um intrincado jogo de madeiras formando a base. Tinha forração de tecido e pintura, que Soares relata terem sido muito bem feitas pelos artífices da pintura, usando diferentes padrões de xadrez com aplicação de ouro pintado. Havia estruturas na lateral que permitiam que atores que faziam o papel de Atlantes, ficassem apoiados.

Além de ter sido construídos em degraus, o que gerou vários níveis de altura, o carro tinha duas colunas e um pedestal "fingindo pedra do mais alto e belo mármore ao pedestal e mármore amarelo" ou seja, tinham uma pintura cenográfica. No carro iam dezesseis músicos. As rodas do carro eram vermelhas e das quartelas do carro saiam festões de flores. As bandeiras que iam atrás eram as dos mouros vencidos, e eram vermelhas com meias luas na cor prata. Havia também diferentes tecidos coloridos ao longo do carro, alguns com franjas douradas.

Mas havia mais, além de todos os atores, a música, as frases e palavras diferentes ao longo do carro (Prudência, Temperança, Triunfo, Paz, Viva, Non plus ultra...), dos tecidos salpicados de ouro e prata: perfume. Duas personagens traziam ânforas e liberavam cheiro no trajeto, mas quando chegou na "arena", onde estavam as autoridades em camarotes construídos, o carro tinha um sistema de bicos que liberavam perfume e lavaram a arena em que terminava o desfile.

Não bastasse toda essa pompa, o carro era puxado por quatro cavalos com cavalheiros distintamente vestidos, como será visto. Antes deles, um cavaleiro montado em um cavalo também ornado, e este cavaleiro era seguido de dois andarilhos, também em roupas formais.

Atrás do carro, iam 24 cavaleiros em "briosos cavalos ajaezados primorosamente" (SOARES, 1786, p. 11). Cada cavaleiro tinha um acompanhante que ia a pé, um "andarino", como os chamou Soares. Ou seja, mais 24 homens. Atrás de toda esta armação, ia um acompanhamento de 16 homens que levavam quatro caixões pintados de "diversas pinturas em que iam as lanças e os aparelhos para as cavalhadas" (Idem, p. 12). Vinham anda quatro carroças que levavam mais quatro arcas grandes, com equipamento para as cavalhadas.

Seguia um cavaleiro sozinho, em cima de uma burra, antes de um carro burlesco, que seria o sexto carro, em que um músico era visto tocando órgão entre as ruínas de um edifício, com acabamento também bastante realista. Mais 24 cavaleiros lúdicos seguiam este carro 12 vestidos de doutores e 12 de viúvas - todos homens.

Tudo isso regado a muita música.

\section{Os trajes de cena}

Pelo que se pode apreender da leitura dos Magníficos carros, os trajes chegaram ao evento de várias formas:

- Trajes que foram confeccionados para uso em cena: "uma figura trapejada de cetim cor de ouro com a sua fita branca com letras de ouro, que diziam: Triunfo" (SOARES, 1786, p. 8). Outro: "Himeneu vestido à trágica, com roupa larga de cetim cor de nácar, guarnecida de galão de prata, cabelos soltos e com uma grinalda de diversas flores" (Idem, p. 9);

- Trajes de uso cotidiano dos militares: "Pu- 
xado o dito carro pelos tirantes e pelos cavalos de uso e serviço do Ilustríssimo e Excelentíssimo Senhor Vice-Rei, bem ajaezados e governados estes pelos seus cocheiros, vestidos com as librés ricas de sua excelência, com chapéus guarnecidos de plumas brancas" (Idem, p. 9);

- Trajes feitos para as cavalhadas, ou seja, trajes de folguedos. "Os cavaleiros vestidos com casacas curtas brancas, 12 com véstias de cetim azul claro agaloadas de ouro, peito e canhões das casas dos mesmos cetins com bandas ao tiracolo azul e barretinas na cabeça azuis guarnecidas de galões de ouro e de preciosas jóias com seus laços de pedras preciosas, e cocais" (Idem, p. 10);

- Trajes de uso social que foram empregados nas festividades, como no caso dos músicos, que foram com "seus vestidos particulares dos mais ricos que tinham e fizeram para as reais festas" (Idem, p. 11).

Duas situações de nu são sugeridas no texto: as bacantes e os sátiros. No caso das primeiras, "saíram do monte 16 bacantes vestidas cor de carne, que pareciam nuas, guarnecidas pela cintura e cabeça com folhas, que pareciam naturais" (Idem, p. 13) e com relação aos sátiros, "todos com redomas de licores nas mãos, coroados e cingidos pela cintura com folhas de parras e vestidos justos cor de carne que pareciam nus" (Idem, p. 16). Os trajes justos cobriam apenas corpos masculinos, já que os papéis das bacantes foram feitos por homens também, como era hábito no período.

Os trajes do Imperador e da Imperatriz tinham que ser grandiosos:

O Imperador e Imperatriz vestidos com vestidos a Mourisca das mais ricas sedas de matizes de várias cores, guarnecido com galões e ouro e prata, e nos pescoços e braços, com seus ornatos de muitas pérolas e aljofres e nas cabeças grandiosos turbantes das mais finas lãs e fitas passadas de ouro e prata, com plumas e os turbantes também guarnecidos com pérolas e aljofres (Idem, p.18).

Interessante também a quantidade de adereços descritos, bem como de calçados. O traje dos animais foi uma atração à parte. Como no caso da burrinha do carro depois das cavalhadas: "Uma burra de pequena estatura, vestida esta com anquinhas, saias, brincos e uma grandiosa lamparina na cabeça que causou muito gosto a todos" (Idem, p. 12).

Já existia atividade teatral no século XVIII no Rio, de forma que, se necessário, alguns materiais poderiam ser encontrados nos teatros. Não faltavam, no entanto, lojas que vendessem materiais dos mais diversos tipos.

No livro Para vestir a cena contemporânea - moldes e moda no Brasil do século XVIII, os autores deste texto citam a obra de Claudia Maria das Graças Chaves, Perfeitos negociantes. Ela esclarece que os mercados do Rio de Janeiro e São Paulo abasteciam o mercado pelos caminhos de Minas e outras localidades. Ela cita três tipos de lugares em Minas que se julga possível aplicar ao esquema do Rio de Janeiro:

Vendas: não vendiam apenas bebidas alcoólicas, mas toda a espécie de comestíveis. Era comum a divisão de espaço entre os gêneros secos - guarda-chuvas, ferraduras, chapéus, espelhos, cintos, facas, garruchas, munição e linha de costura e os comestíveis - cachaça, sal, rapaduras, feijão, milho, toucinho e carne salgada.

Lojas: limitavam-se a vender apenas fazendas secas, entre elas, os têxteis. Uma das autoras que ela consultou diz que as lojas eram maiores, mais bem abastecidas, tanto de secos e molhados como de remédios e outros itens.

Tavernas: locais que comercializavam apenas bebidas, especialmente a aguardente. (CHAVES apud VIANA; ITALIANO, 2018, p. 91).

Mas também é claro que o nível de comércio de bens e produtos no Rio de Janeiro é muito maior, como destaca Cavalcanti, citado por Viana e Italiano:

Os homens do comércio no Rio de Janeiro poderiam ser alinhados em três grandes conjuntos:

- Comerciantes miúdos, chamados "retalhistas", ou "homens de vara", ou ainda, "mercadores de loja";

- Negociantes de "grosso trato" ou de "so- 
brado", formado de destacados importadores e exportadores, senhores de grande cabedal;

- Os capitalistas, aqueles que "viviam de seus bens ou rendas", participando eventualmente da compra e arremate de mercadorias e da sua revenda, sem contudo se organizarem formalmente por meio de firma estabelecida (CAVALCANTI apud ITALIANO; VIANA, 2018, p.92-93).

Esses importadores traziam não só roupas prontas como também tecidos os mais variados, como encontrado em levantamentos feitos por Marco Aurélio Drumond (DRUMOND apud VIANA; ITALIANO, 2018): baeta, bretanha, brim, camelão, chamalote, china, crepe, damasco, duquesa, fustão, holanda, lemiste, linhagem, linho, nobreza, pano, renda, ruão, saeta, sarja, seda, tafetá e veludo, entre outros.

Quanto à preocupação de quem executaria os trajes, o Rio de Janeiro já contava desde o século XVI com profissionais ligados a alfaiataria e adereços de cabeça, como chapéus. No século XVIII, Drumond exemplifica com os profissionais existentes na Comarca do Rio das Velhas:

Alfaiates, sapateiros, costureiras e tecelões, destacaram-se entre os oficiais especializados na confecção dos diversos artigos indumentários que compunham o traje ordinário e extraordinário da sociedade mineradora. Ao lado dos alfaiates que confeccionavam peças de roupa com maior rigor técnico e com os mais diversos tecidos, existiu uma produção caseira de fios, tecidos e roupas rústicas que abastecia a maioria da população. Fosse para abastecer o mercado de tecidos grosseiros ou mesmo para o consumo familiar, diversas famílias estiveram envolvidas com essa produção" (DRUMOND, 2008, p. 36).

A partir disso, é possível imaginar quantos estariam disponíveis nos maiores centros urbanos do país no século XVIII: o Rio de Janeiro e Salvador.

\section{Apontamentos finais}

Não foi apenas uma festa de comemoração de um casamento entre uma criança de
10 anos e um jovem de 18: foi uma experiência política. Era a oportunidade de ouro para que o Vice-rei mostrasse que seu trabalho à frente da administração do reino estava sendo bem sucedido.

No entanto, foi também uma boa oportunidade de mostrar que o país já tinha tecnologia - e algum conhecimento artístico - para fazer um "espetáculo" do tipo que foi apresentado. Usando um conceito contemporâneo de teatro expandido, será possível perceber que é justamente disso que se trata. Foi um trabalho repleto de teatralidade, como o entende a pesquisadora e professora Sílvia Fernandes:

A teatralidade pode ser uma maneira de atenuar o real para torná-lo estético; ou um modo de sublinhar este real com um traçado cênico obsessivo, a fim de reconhecê-lo e compreender o político; ou um embate de regimes ficcionais distintos que impede a encenação de construir-se a partir de um único ponto de vista, e abre múltiplos focos de olhar em disputa pela primazia de observação do mundo (FERNANDES, 2011, p.12).

A manipulação dos materiais empregados na cenografia e nos trajes de cena foi impressionante, com resultado rico e visualmente impactante e, pela descrição, muito funcional no sentido de atingir e captar a atenção do público.

Quanto ao livreto Relação dos magníficos carros, é bem verdade que sua autenticidade poderia ser questionada. Mas como foi entregue ao Instituto Histórico e Geográfico por pessoa muito responsável, o pintor e professor Manuel de Araújo Porto-Alegre, percebe-se que a descrição no livro busca ser a mais fidedigna possível, com relação aos eventos acontecidos. Como registro histórico de cenografia e figurinos, é provavelmente o mais bem ilustrado e descrito que se tem até o século XVIII, o que, mais uma vez, reforça a importância da preservação da memória teatral para as gerações futuras, de modo a assegurar a existência de valores da cultura, do conhecimento e da identidade 


\section{REFERÊNCIAS}

BERTHOLD, Margot. História mundial do teatro. São Paulo: Perspectiva, 2010.

BLUTEAU, Raphael. Vocabulario portuguez \& latino: aulico, anatomico, architectonico. V. 8. Coimbra: Collegio das Artes da Companhia de Jesus, 1712 - 1728.

CAVALCANTI, Nireu. O Rio de Janeiro setecentista: a vida e a construção da cidade da invasão francesa até a chegada da Corte. Rio de Janeiro: Zahar, 2004.

CHAVES, Claudia Maria das Graças. Perfeitos negociantes: mercadores das Minas setecentistas. São Paulo: Annablume, 1999.

DRUMOND, Marco Aurélio. Indumentária e Cultura Material: Produção, comércio e usos na Comarca do Rio das Velhas (1711-1750). 2008. 217 f. Dissertação (Mestrado em história) - Universidade Federal de Minas Gerais, Faculdade de Filosofia e Ciências Humanas, Belo Horizonte, MG.

FERREIRA, Felipe. O marquês e o jegue. Rio de Janeiro: Altos da Glória, 1999.

HERNANDES, Paulo Romualdo. José de Anchieta, o teatro e a educação dos moços no Colégio de Jesus na Bahia do século XVI. Revista HISTEDBR On-line, Campinas, SP, n.47, p.24-42, set. 2012. Disponível em: <https://periodicos.sbu. unicamp.br/ojs/index.php/histedbr/article/download/8640037/7596>. Acesso em 15 jan. 2019.

HOLME, Bryan. Princely feasts and festivals - five centuries of pageantry and spectacle. Nova York: Thames and Hudson, 1988.

JARDIM, Maria do Rosário. A baixela Germain a serviço da corte no Reinado de D. Maria I. Revista Artigo em linha, Lisboa, Portugal, n. 6. 2012. Disponível em: <http://www.palacioajuda.gov.pt/Data/Documents/Artigos/A\%20Baixela\%20Germain\%20ao\%20servi\%C3\%A7o\%20da\%20Corte.pdf>. Acesso em 14 jan. 2019.

LEITE, Serafim. História da Companhia de Jesus no Brasil. V. 1. Organização de César Augusto dos Santos et al. São Paulo: Edições Loyola, 2004.

PEREIRA, Sonia Gomes. Festas públicas e desenvolvimento urbano no Rio de Janeiro do século XVIII. Disponível em: <https://www.upo.es/depa/webdhuma/ areas/arte/3cb/documentos/101f.pdf.>. Acesso em: 14 jan. 2019. 


\section{REFERÊNCIAS}

RAMOS, Rui. História de Portugal. Lisboa: A Esfera dos livros, 2012.

ROBERTS, Jenifer. D. Maria I - a vida notável de uma rainha louca. Alfragide: Casa das Letras, 2009.

SOARES, Antonio José. Relação dos Magníficos carros, que se fizerão de arquitetura, perspectiva e fogos. Os quais, se executaram Por Ordem do Illust.mo e Excel.mo Senhor Luis de Vasconcelos, Capitão General de Mar e Terra, e Vice Rei dos Estados do Brazil, nas Festividades dos Despozorios Dos Serenissimos Senhores Infantes de Portugal - Nesta Cidade Capital do Rio de Janeiro. Em 2 de Fevereiro de 1786. Feita na Praça mais Lustroza, e publica do passeio desta cidade. Executados, e ideados, pelo O mínimo subdito Antônio Fran.co Soares Ajudante agregado. Rio de Janeiro: [s.n.], 1786.

TINHORÃO, José Ramos. As festas no Brasil colonial. São Paulo: Editora 34, 2000.

VIANA, Fausto. The Clothes Worn in 1785 for the Betrothal and Wedding of Carlota Joaquina of Spain and Dom João of Portugal. The Journal of Dress History, London, v.1, n.2, 17p. Separata de The Association of Dress Historians. London, England, Autumn 2017.

VIANA, Fausto; ITALIANO, Isabel. Para vestir a cena contemporânea: moldes e moda no Brasil do século XVIII. São Paulo: ECA-USP, 2018. 


\begin{abstract}
This article presents the scenography used in the celebration of the marriage of D. João VI and Da. Carlota Joaquina, in 1786, in Rio de Janeiro. The celebration, described in the document Relação dos Magníficos carros, que se fizeram de arquitetura, perspectiva e fogos has outstanding importance, being one of the most important, and perhaps the oldest set of drawings produced in Brazil up to 1786, as a document of popular feast, full of theatricality.
\end{abstract}

\title{
Keywords
}

Set design. Costume design. Colonial Brazil.

\section{Resumen}

Este artículo presenta la escenografía empleada en la fiesta de celebración del matrimonio de D. João VI y Doña. Carlota Joaquina, que ocurrió en 1786, en Río de Janeiro. La celebración, descrita en el libreto Relação dos Magnificos carros, que se fizeram de arquitetura, perspectiva e fogos, tiene destacada importancia, por ser uno de los más importantes, y tal vez el más antiguo conjunto de dibujos producidos en Brasil hasta 1786, como documento de fiesta popular, repleta de teatralidad.

\section{Palabras clave}

Escenografía. Traje de escena. Brasil colonial. 